\title{
PELAKSANAAN SUPERVISI AKADEMIK \\ UNTUK MENINGKATKAN KOMPETENSI GURU \\ DALAM MENYUSUN TES HASIL BELAJAR BERBASIS KETERAMPILAN BERPIKIR KRITIS
}

\author{
Sungep \\ sungepspd@gmail.com \\ SD Negeri 006 Pontian Mekar, Indragiri Hulu, Indonesia
}

\begin{abstract}
This study refers to the teacher's competence in compiling tests of learning outcomes that are still low and seems to be a condition for the availability of the test only, even though the test is used as a benchmark for students' abilities after experiencing the learning process. For this reason, this study aims to guide teachers in developing learning outcomes tests, especially those based on critical thinking skills. This research is a classroom action research conducted on 24 teachers of 006 Pontian Mekar Elementary School. The research will be carried out from July to August 2019. Data analysis uses observation sheets. The results showed an increase in teacher competency in preparing critical thinking skills learning outcomes test with a percentage in the construction aspect I of $72 \%$ with a quite appropriate category to $85 \%$ which is included in the appropriate category, in the material aspect in the cycle I gained a percentage of $75 \%$ which is a category quite appropriate increased to reach $87 \%$ which is classified in the category of very appropriate, and for aspects of language also increased from $68 \%$ in the first cycle increased to $82 \%$ in the second cycle. The conclusion of this study is that the implementation of academic supervision can improve teacher competence in compiling tests of learning outcomes based on critical thinking skills.
\end{abstract}

Keywords: academic supervision, teacher competence, learning achievement test, critical thinking skills

\section{ABSTRAK}

Penelitian ini mengacu kompetensi guru dalam menyusun tes hasil belajar yang masih rendah dan terkesan sebagai syarat ketersediaan tes semata, padahal tes dijadikan sebagai tolok ukur kemampuan siswa setelah mengalami proses belajar mengajar. Untuk itu penelitian ini bertujuan untuk membimbing guru dalam menyusun tes hasil belajar khususnya berbasis keterampilan berpikir kritis. Penelitian ini merupakan penelitian tindakan kelas yang dilakukan pada 24 orang guru SD Negeri 006 Pontian Mekar. Pelaksanaan penelitian dimulai dari bulan Juli sampai Agustus 2019. Analisis data menggunakan lembar observasi. Hasil penelitian menujukkan adanya peningkatan kompetensi guru dalam menyusun tes hasil belajar berbasis keterampilan berpikir kritis dengan persentase pada aspek konstruksi I sebesar 72\% dengan kategori cukup sesuai menjadi $85 \%$ yang termasuk kategori sesuai, pada aspek materi pada siklus I memperoleh persentase $75 \%$ yang merupakan kategori cukup sesuai meningkat mencapai $87 \%$ yang tergolong dalam kategori sangat sesuai, dan untuk aspek bahasa juga mengalami peningkatan dari $68 \%$ pada siklus I meningkat menjadi $82 \%$ pada siklus II. Kesimpulan penelitian ini adalah pelaksaaan supervisi akademik dapat meningkatkan kompetensi guru dalam menyusun tes hasil belajar berbasis keterampilan berpikir kritis.

Kata Kunci: supervisi akademik, kompetensi guru, tes hasil belajar, keterampilan berpikir kritis

\begin{tabular}{|c|c|c|}
\hline Submitted & Accepted & Published \\
\hline 23 Juni 2019 & 04 Oktober 2019 & 14 November 2019 \\
\hline
\end{tabular}

\begin{tabular}{|l|c|c|}
\hline Citation & $:$ & $\begin{array}{r}\text { Sungep. (2019). Pelaksanaan Supervisi Akademik untuk Meningkatkan Kompetensi Guru dalam Menyusun Tes Hasil } \\
\text { Belajar Berbasis Keterampilan Berpikir Kritis. Jurnal PAJAR (Pendidikan dan Pengajaran), 3(6), 1332-1340. } \\
\text { DOI : http://dx.doi.org/10.33578/pjr.v3i6.7896. }\end{array}$ \\
\hline
\end{tabular}

\section{PENDAHULUAN}

Pendidikan membekali siswa dalam mengembangkan potensi diri agar memiliki akhlak mulia, kepribadian yang cerdas, kemampuan berpikir secara totalitas, serta keterampilan oleh dirinya, masyarakat, bangsa dan Negara. Untuk mewujudkan itu semua perlu peran aktif serta kemampuan seorang pendidik yang memiliki kewajiban: a) menciptakan suasana pendidikan yang bermakna, menyenangkan, kreatif, dinamis, dan dialogis; b) mempunyai komitmen secara profesional untuk meningkatkan mutu pendidikan; dan c) memberi teladan dan menjaga nama baik lembaga, profesi, 
dan kedudukan sesuai dengan kepercayaan yang diberikan kepadanya (Depdiknas, 2003).

Sebagai upaya meningkatkan mutu pendidikan, guru dituntut untuk mampu menyiapkan, mengolah proses pembelajaran, membuat instrumen tes, serta menganalisis perkembangan pembelajaran secara utuh. Saat ini kementerian pendidikan dan kebudayaan melalui direktorat jenderal guru dan tenaga kependidikan (Ditjen GTK) berupaya mengembangkan pembelajaran berorientasi pada keterampilan berpikir tingkat tinggi atau dikenal dengan istilah High Order Thinking Skills (HOTS) dalam upaya peningkatan kualitas pembelajaran dan lulusan.

Guru yang cakap dalam merencanakan dan menyiapkan pembelajaran, mengolah proses pembelajaran, membuat instrumen tes, serta menganalisis pembelajaran akan menghasilkan siswa yang memiliki kreativitas dan prestasi yang baik. Untuk mengumpulkan data penelitian tentang hasil belajar atau prestasi belajar bisa dilakukan dengan memakai instrumen tes, dalam penelitian ini diupayakan guru mampu menyusun instrumen tes hasil belajar dengan baik, salah satunya adalah instrumen tes berbasis keterampilan berpikir kritis.

\section{KAJIAN TEORETIS Supervisi Akademik}

Supervisi akademik merupakan tindakan seseorang yang memiliki peran dalam instansi pendidikan seperti pengawas atau kepala sekolah dalam bentuk bantuan terhadap guru untuk meningkatkan dan mengembangkan kemampuan guru dengan melakukan bimbingan mulai dari perencanaan sampai evaluasi pembelajaran (Rambe, 2019). Menurut Asniarny (2019) dan Basri (2019) supervisi akademik adalah usaha kepala sekolah atau pengawas dalam membantu, membina, membimbing dan mengembangkan kemampuan guru dalam mewujudkan fungsi sebagai pendidik. Merujuk pengertian yang dikemukakan, dapat ditarik kesimpulan bahwa supervisi merupakan upaya yang dilakukan profesional seperti pengawas maupun kepala sekolah terhadap guru dalam meningkatkan kompetensi sebagai pendidik.
Peneliti melakukan pengamatan terhadap instrumen yang dibuat oleh guru yang dijadikan sebagai alat ukur keberhasilan yang digunakan pada ujian harian. Fakta di lapangan ditemukan bahwa: 1) instrumen tes yang digunakan belum mengukur kemampuan sesuai kompetensi dasar dan tujuan pembelajaran yang diajarkan pada siswa, 2) instrumen tes yang digunakan tidak mengacu pada keterampilan berpikir tingkat tinggi, khususnya keterampilan berpikir kritis, 3) keterbacaan soal belum mengacu pada bahasa Indonesia yang baik dan benar serta sesuai dengan tingkat pemahaman siswa. Penelitian lain juga menjelaskan bahwa banyak guru yang belum dapat menyusun butir soal dengan baik (Gusmarni, 2019).

Kompetensi guru dalam menyusun tes hasil belajar berbasis keterampilan berpikir kritis mengalami peningkatan setelah dilaksanakan supervisi akademik (Suryani, 2019). Mengacu pada fakta tersebut, peneliti berupaya meningkatkan kompetensi guru SDN 006 Pontian Mekar dalam menyusun tes hasil belajar yang mampu mengukur kemampuan siswa khususnya keterampilan berpikir kritis melalui pelaksanaan supervisi akademik.

Supervisi akademik bertujuan untuk untuk membantu guru mengembangkan kompetensinya, mengembangkan kurikulum, mengembangkan kelompok kerja guru, dan membimbing penelitian tindakan kelas (PTK) (Suriati, 2018). Dalam penelitian ini, supervisi yang dilakukan bertujuan untuk meningkatkan kompetensi guru dalam menyusun tes hasil belajar siswa berbasis keterampilan berpikir kritis.

\section{Kompetensi Guru}

Sujarno (2019) dan Baharuddin (2019) mengemukakan bahwa kompetensi guru merupakan penguasaan terhadap pengetahuan, keterampilan, nilai dan sikap yang direfleksikan dalam kebiasaan berpikir dan bertindak dalam menjalankan profesi sebagai guru. Lebih lanjut Maisuherni (2019) menyatakan bahwa kompetensi guru adalah kemampuan guru dalam mengintegrasikan pengetahuan, sikap, dan keterampilan untuk mencapai tujuan pembelajaran 
dan pendidikan berdasarkan pengalaman pembelajaran yang dilakukan. Merujuk dari pernyataan tersebut dapat disimpulkan bahwa kompetensi guru adalah kemampuan guru berupa pengetahuan, sikap, dan keterampilan dalam melaksanakan proses pembelajaran.

\section{Tes Hasil Belajar Berbasis Keterampilan Berpikir Kritis}

Pada dasarnya penilaian memiliki tujuan untuk memperoleh informasi mengenai perkembangan proses dan hasil belajar siswa dan hasil mengajar guru. Informasi mengenai hasil penilaian proses dan hasil belajar serta hasil mengajar yaitu berupa penguasaan indikatorindikator dari kompetensi dasar yang telah ditetapkan. Hal ini dapat digunakan sebagai sarana untuk memotivasi siswa dalam pencapaian kompetensi dasar, melaksanakan program remidial serta mengevaluasi kemampuan guru dalam rangka meningkatkan kualitas pembelajaran. Dalam rangka melakukan pengukuran atau penilaian, seseorang membutuhkan alat ukur salah satunya adalah tes. Menurut Sudijono (2011), tes adalah cara (yang dapat dipergunakan) atau prosedur (yang perlu ditempuh) dalam rangka pengukuran dan penilaian di bidang pendidikan, yang berbentuk pemberian tugas atau serangkaian tugas baik berupa pertanyaan-pertanyaan (yang harus dijawab), atau perintah-perintah (yang harus dikerjakan), sehingga (atas dasar data yang diperoleh dari hasil pengukuran tersebut) dapat dihasilkan nilai yang melambangkan tingkah laku atau prestasi testee; nilai-nilai yang dicapai oleh testee dapat dibandingkan dengan nilai standar tertentu seperti KKM.

Dalam penilaian proses dan hasil belajar siswa di sekolah, aspek yang berkenaan dengan pemilihan alat penilaian, yaitu; penyusunan soal, analisis butir soal untuk memperoleh kualitas soal yang memadai, dan pengolahan dan interpretasi data hasil penilaian. Menurut Arikunto, tes yang baik harus mempunyai syarat-syarat antara lain: 1) harus efisien (parsimony), 2) harus baku (standardize), 3) mempunyai norma, 4) objektif, 5) valid (sahih), dan 6) reliabel (andal). Oleh sebab itu untuk memperoleh tes yang baik, tes tersebut harus di ujicobakan terlebih dahulu dan hasilnya dianalisis sehingga memenuhi syaratsyarat tersebut di atas.

Pedoman dalam penulisan tes mengacu pada 3 aspek, sesuai yang dinyatakan Basuki dan Hariyanto (2015) yaitu aspek materi, aspek konstruksi, dan aspek bahasa. Karakteristik aspek materi meliputi: (a) soal sesuai dengan indikator (menuntut tes tertulis untuk pilihan ganda), (b) materi yang ditanyakan sesuai dengan komposisi (urgensi, relevansi, kontinuitas, keterpakaian sehari-hari tinggi), (c) pilihan jawaban homogen dan logis, (d) hanya ada satu kunci jawaban yang benar. Karakteristik aspek konstruksi meliputi: (a) Pokok soal dirumuskan dengan singkat, jelas, dan tegas. (b) Rumusan pokok soal dan pilihan jawaban merupakan pernyataan yang diperlukan saja. (c) Pokok soal memberi petunjuk kunci jawaban. (d) Pokok soal bebas dari pernyataan yang bersifat negatif ganda. (e) Pokok soal memberi petunjuk kunci jawaban. (f) Pokok soal bebas dari pernyataan yang bersifat negatif ganda. (g) Pilihan jawaban homogen dan logis ditinjau dari segi materi. (h) Gambar, grafik, tabel, diagram, atau sejenisnya jelas dan berfungsi. (i) Panjang pilihan jawaban relatif sama. (j) Pilihan jawaban tidak menggunakan pernyataan "semua jawaban di atas salah/ benar" dan sejenisnya. (k) Pilihan jawaban berbentuk angka/ waktu disusun berdasarkan urutan besar kecilnya angka atau kronologisnya. (1) Butir soal bergantug pada jawaban soal sebelumnya. Dan karakteristik aspek bahasa meliputi: (a) Menggunakan bahasa yang sesuai dengan kaidah bahasa Indonesia. (b) Menggunakan bahasa yang komunikatif. (c) Tidak menggunakan bahasa yang berlaku setempat/ tabu. (d) Pilihan jawaban tidak mengulang kata/kelompok kata yang sama, kecuali merupakan satu kesatuan pengertian. (e) Kalimat soal tidak menyalin/ menjiplak persis suatu teks bacaan. (f) Kalimat dalam pokok soal tidak menyinggung pribadi seseorang, suku, ras, dan agama.

Tes yang digunakan berbentuk pilihan ganda. Lebih lanjut dapat dilihat pada tabel kartu telaah soal pilihan ganda berikut. 
Tabel 1. Kartu Telaah Soal Pilihan Ganda

\begin{tabular}{|c|c|c|}
\hline No & Aspek & Kriteria Penilaian \\
\hline \multirow[t]{8}{*}{1} & Konstruksi & 1. Pokok soal diekspresikan dalam bentuk yang sesuai \\
\hline & & 2. Pokok soal tidak menimbulkan pengertian ganda \\
\hline & & 3. Pokok soal tidak memberi petunjuk pada jawaban benar \\
\hline & & 4. Pokok soal mandiri \\
\hline & & 5. Pokok soal mengondisikan siswa berpikir analitik \\
\hline & & 6. Pilihan jawaban merujuk urutan yang benar \\
\hline & & 7. Pengecoh homogen \\
\hline & & 8. Hanya ada satu jawaban yang benar. \\
\hline \multirow[t]{3}{*}{2} & Materi Tes & 1. Pokok soal relevan dengan tujuan pembelajaran khusus atau indikator \\
\hline & & 2. Representitas pokok soal relevan dengan perilaku yang diukur \\
\hline & & 3. Spesifikasi pokok soal menurut jenjang perilaku yang diukur \\
\hline \multirow[t]{9}{*}{3} & Bahasa & 1. Pokok soal menerapkan kaidah bahasa Indonesia (EYD) \\
\hline & & 2. Rumusan pilihan jawaban relatif sama panjang \\
\hline & & 3. Pokok soal singkat dan akurat \\
\hline & & 4. Ketepatan pokok soal dengan spesifikasi butir tes \\
\hline & & 5. Kelengkapan teknis pokok soal \\
\hline & & 6. Pokok soal tidak opensif \\
\hline & & 7. Pokok soal tidak bisa budaya \\
\hline & & 8. Pokok soal komunikatif \\
\hline & & 9. Pokok soal padat dan lugas \\
\hline
\end{tabular}

(dalam Gusmarni, 2019)

Tes hasil belajar yang disusun berbasis keterampilan berpikir kritis, keterampilan ini termasuk dalam higher order thinking skills atau keterampilan berpikir tingkat tinggi. Berpikir kritis merupakan sebuah proses yang terarah dan jelas yang digunakan dalam kegiatan mental seperti memecahkan masalah, mengambil keputusan, membujuk, menganalisis asumsi, dan melakukan penelitian ilmiah (Kartimi \& Liliasari, 2012).

Pada dasarnya keterampilan berpikir kritis menurut Ennis (dalam Asmawati, 2018) dikembangkan menjadi indikator-indikator keterampilan berpikir kritis yang terdiri dari lima kelompok besar yaitu, (1) Memberikan penjelasan sederhana (elementary clarification), meliputi: (a) mengidentifikasi atau merumuskan pertanyaan, (b) menganalisis argumen, dan (c) bertanya dan

\section{METODE PENELITIAN}

Penelitian ini menggunakan metode school action research atau penelitian tindakan sekolah terhadap guru SD Negeri 006 Pontian Mekar yang berjumlah 24 orang guru. Penelitian ini dilakukan mulai dari bulan Juli sampai menjawab pertanyaan klarifikasi dan atau pertanyaan yang menantang.; (2) Membangun keterampilan dasar (basic support), meliputi: (a) mempertimbangkan kredibilitas suatu sumber dan (b) mengobservasi dan mempertimbangkan hasil observasi.; (3) Menyimpulkan (interference) meliputi: (a) membuat deduksi dan mempertimbangkan hasil deduksi, (b) membuat induksi dan mempertimbangkan hasil induksi, dan (c) membuat dan mempertimbangkan nilai keputusan; (4) Memberikan penjelasan lebih lanjut (advanced clarification) meliputi: (a) mengidentifikasikan istilah dan mempertimbangkan definisi dan (b) mengacu pada asumsi yang tidak dinyatakan.; (5) Mengatur strategi dan taktik (strategy dan tactics) meliputi: (a) Menentukan suatu tindakan, (b) Berinteraksi dengan orang lain

Agustus 2019. Menurut Mulyasa (dalam Asnidawati, 2019) PTS adalah sebuah penelitian yang berupaya untuk memperbaiki keadaan dan memecahkan permasalahan pendidikan yang dialami guru di sekolah. Prosedur penelitian ini 
dimulai dari perencanaan, pelaksanaan, observasi, dan refleksi.

Teknik Analisis Data

Kompetensi guru dipantau melalui lembar observasi yang disesuaikan dengan kartu telaah. Observasi dilakukan oleh kepala sekolah meliputi aspek materi, konstruksi, dan bahasa yang berbasis pada indikator keterampilan berpikir kritis. Data dianalisis menggunakan rubrik penilaian disesuaikan dengan aspek konstruksi, materi, dan bahasa yang berbasis keterampilan berpikir kritis, diberi skor 1 jika soal tes tidak sesuai dengan indikator, skor 2 jika kurang, skor 3 jika cukup, skor 4 jika sesuai, skor 5 jika sangat sesuai. Untuk mengukur hasil penilaian dari observasi yang dilakukan dapat menggunakan rumus berikut:

Persentase nilai $=\frac{\text { skor } \text { yang diperoleh }}{\text { skor maksimal }} \times 100 \%$

(Yustimar, 2016)

Setelah persentase nilai kompetensi guru diperoleh, selanjutnya menentukan interval penilaian tersebut berdasarkan kategori berikut

Tabel 2. Interval Penilaian Kompetensi Guru dalam Penyusunan Tes Berbasis Keterampilan Berpikir Kritis

\begin{tabular}{cc}
\hline Nilai & Kategori \\
\hline $86-100$ & Sangat Sesuai (SS) \\
$76-85$ & Sesuai (S) \\
$60-75$ & Cukup Sesuai (CS) \\
$50-59$ & Kurang Sesuai (KS) \\
$\leq 49$ & Tidak Sesuai (TS)
\end{tabular}

Adaptasi dari Gusmarni 2019

Indikator keberhasilan dalam penelitian ini adalah rata-rata $80 \%$ guru mampu menyusun tes hasil belajar berbasis keterampilan berpikir kritis dengan kategori sesuai tujuan, materi, dan bahasa. Hal ini diharapkan agar instrumen yang

\section{HASIL DAN PEMBAHASAN}

Siklus I

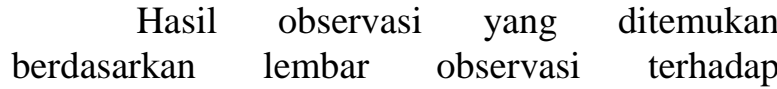

disusun dapat memenuhi tujuan pembelajaran, materi yang diujikan, serta Bahasa yang baik, benar, dan komunikatif yang pada akhirnya dapat meningkatkan kemampuan siswa berpikir tingkat tinggi.

kompetensi guru dalam menyusun tes hasil belajar adalah sebagai berikut:

Tabel 3. Rekapitulasi Penilaian Kompetensi Guru dalam Menyusunan Tes Hasil Belajar Berbasis Keterampilan Berpikir Kritis Siklus I

\begin{tabular}{ccccc}
\hline No & Guru & Aspek Konstruksi & $\begin{array}{c}\text { Aspek yang diamati } \\
\text { Aspek Materi }\end{array}$ & Aspek Bahasa \\
\hline 1 & A & 3 & 4 & 3 \\
2 & B & 2 & 3 & 2 \\
3 & C & 4 & 2 & 3 \\
4 & D & 3 & 4 & 2 \\
5 & E & 3 & 3 & 2 \\
6 & F & 2 & 3 & 3 \\
7 & G & 3 & 2 & 2 \\
8 & H & 2 & 4 & 3 \\
9 & I & 2 & 3 & 2
\end{tabular}




\begin{tabular}{llccc}
10 & J & 4 & 2 & 4 \\
11 & $\mathrm{~K}$ & 3 & 4 & 3 \\
12 & $\mathrm{~L}$ & 3 & 3 & 4 \\
13 & $\mathrm{M}$ & 4 & 2 & 3 \\
14 & $\mathrm{~N}$ & 2 & 4 & 3 \\
15 & $\mathrm{O}$ & 3 & 3 & 4 \\
16 & $\mathrm{P}$ & 4 & 2 & 3 \\
17 & $\mathrm{Q}$ & 2 & 3 & 2 \\
18 & $\mathrm{R}$ & 3 & 3 & 2 \\
19 & $\mathrm{~S}$ & 2 & 4 & 3 \\
20 & $\mathrm{~T}$ & 4 & 2 & 3 \\
21 & $\mathrm{U}$ & 2 & 3 & 2 \\
22 & $\mathrm{~V}$ & 4 & 2 & 3 \\
23 & $\mathrm{~W}$ & 3 & 3 & $\mathbf{6 8 \%}$ \\
24 & $\mathrm{X}$ & 3 & $\mathbf{7 5 \%}$ & $\mathbf{C S}$ \\
\hline
\end{tabular}

Tabel 3 menujukkan bahwa rata-rata tes hasil belajar berbasis keterampilan berpikir kritis yang disusun oleh guru pada aspek konstruksi $72 \%$ dengan kategori cukup sesuai, aspek materi 75\% yang termasuk kategori cukup sesuai, dan aspek bahasa dengan persentase sebesar 68\% yang juga temasuk kategori cukup sesuai. Hal ini memperlihatkan bahwa kompetensi guru belum sesuai dengan harapan dan perlu ditingkatkan lagi.

Berdasarkan catatan dari hasil observasi ditemukan kendala dalam penyusunan tes, diantaranya: 1) aspek konstruksi masih banyak guru yang belum menyesuaikan tujuan dan kompetensi dasar siswa dengan indikator keterampilan berpikir kritis. Guru masih belum membuat pertanyaan untuk menjelaskan suatu materi, belum adanya pertanyaan berdasarkan hasil pengamatan siswa, belum terdapat pertanyaan yang dapat menyimpulkan suatu pernyataan, tidak adanya pertanyaan lanjutan, serta tidak ditemukan soal yang menanyakan strategi; 2) aspek materi belum dapat dijelaskan secara sederhana, sumber materi tidak kontekstual dengan siswa, materi belum dapat ditarik keputusan, masih terdapat materi yang mencantumkan istilah yang kurang dipahami siswa, serta materi tidak disiapkan untuk tindak lanjutan seperti diskusi; 3) aspek bahasa pada penjelasan masih belum sederhana, pertanyaan tidak menggambarkan observasi, bahasa belum bisa membuat pertimbangan pengambilan keputusan, tidak ada bahasa untuk penjelasan lebih lanjut, soal kurang opensif untuk tindakan lanjutan.

Untuk dapat menyusun tes dengan baik maka guru harus memahami materi terlebih dahulu, kemudian menyusun kisi-kisi soal sebagai panduan untuk menyusun soal sesuai aspek dan indikator yang dibuat (Kadarwati, 2017). Merujuk pada hasil siklus I dan masukan di atas yaitu membuat kisi-kisi soal maka melalui supervisi akademik menjadikan perbaikan ini sebagai refleksi untuk siklus II diharapkan menghasilkan tes yang lebih baik.

\section{Siklus II}

Mengacu pada perbaikan refleksi yang dikemukakan pada siklus I, maka pada siklus II peneliti membimbing guru dalam menyusun tes hasil belajar berbasis keterampilan berpikir kritis dengan panduan kisi-kisi soal. Pada siklus II, kompetensi guru mengalami peningkatan yang signifikan, data hasil observasi siklus II dapat dilihat pada tabel berikut: 
Tabel 4. Rekapitulasi Penilaian Kompetensi Guru dalam Menyusunan Tes Hasil Belajar Berbasis Keterampilan Berpikir Kritis Siklus II

\begin{tabular}{ccccc}
\hline No & Guru & Aspek Konstruksi & $\begin{array}{c}\text { Aspek yang diamati } \\
\text { Aspek Materi }\end{array}$ & Aspek Bahasa \\
\hline 1 & A & 3 & 4 & 3 \\
2 & B & 3 & 4 & 3 \\
3 & C & 4 & 3 & 4 \\
4 & D & 3 & 4 & 3 \\
5 & E & 4 & 3 & 3 \\
6 & F & 3 & 4 & 3 \\
7 & G & 3 & 3 & 4 \\
8 & H & 2 & 4 & 3 \\
9 & I & 3 & 3 & 4 \\
10 & J & 4 & 3 & 3 \\
11 & K & 3 & 4 & 4 \\
12 & L & 4 & 4 & 3 \\
13 & M & 4 & 3 & 4 \\
14 & N & 3 & 4 & 4 \\
15 & O & 3 & 3 & 3 \\
16 & P & 4 & 3 & 3 \\
17 & Q & 3 & 4 & 3 \\
18 & R & 4 & 3 & 3 \\
19 & S & 3 & 4 & 3 \\
20 & T & 4 & 3 & 3 \\
21 & U & 3 & 4 & 3 \\
22 & V & 4 & 3 & $\mathbf{8 2 \%}$ \\
24 & W & 4 & 3 & S \\
\hline
\end{tabular}

Berdasarkan data hasil observasi kompetensi guru dalam menyusun tes hasil belajar berbasis keterampilan berpikir kritis siklus II dapat dilihat bahwa pada aspek konstruksi guru memperoleh kompetensi sebesar $85 \%$ yang termasuk kategori sesuai, guru mampu membuat pengecoh soal dengan baik serta menuntut siswa untuk berpikir analitis. $87 \%$ untuk aspek materi yang merupakan kategori sangat sesuai, soal yang dibuat guru sudah sesuai dengan tujuan pembelajaran dan mengukur indikator capaian pembelajaran yang ditetapkan. Sebesar $82 \%$ pada aspek bahasa yang termasuk dalam kategori sesuai, di mana guru dapat membuat rumusan jawaban dengan bobot sama panjang dan komunikatif serta soal dibuat lebih komunikatif tanpa ada pertanyaan yang perlu dipertanyakan alias ambigu. Hal ini berarti kompetensi guru sudah mencapai indikator keberhasilan yang diharapkan oleh peneliti bahwa setidaknya $80 \%$ guru mampu menyusun tes hasil belajar berbasis keterampilan berpikir kritis. Hasil ini senada dengan penelitian Suryani (2019) bahwa kompetensi guru dalam menyusun tes hasil belajar berbasis keterampilan berpikir kritis mengalami peningkatan melalui supervisi akademik. Marimin (2017) memperkuat bahwa kesulitan guru dalam menyusun tes hasil belajar dapat diatasi melalui diskusi dan supervisi akademik. Penelitian lain dalam meningkatkan kompetensi guru dilakukan oleh Kasiono (2019) yang menyatakan bahwa kompetensi guru dalam menyusun soal dapat ditingkatkan melalui teknik pendampingan dengan pola SP3R. 


\section{SIMPULAN DAN REKOMENDASI}

Dari hasil penelitian di atas, maka dapat disimpulkan bahwa melalui supervisi akademik dapat meningkatkan kompetensi guru dalam menyusun tes hasil belajar berbasis keterampilan berpikir kritis. Peningkatan ini dapat dilihat dari aspek konstruksi pada siklus I sebesar $72 \%$ dengan kategori cukup sesuai menjadi $85 \%$ yang termasuk kategori sesuai, pada aspek materi pada siklus I memperoleh persentase $75 \%$ yang merupakan kategori cukup sesuai meningkat mencapai $87 \%$ yang tergolong dalam kategori sangat sesuai, dan untuk aspek bahasa juga

\section{DAFTAR PUSTAKA}

Arikunto, S. (2003). Dasar-Dasar Evaluasi Pendidikan. Jakarta: Bumi Aksara.

Asmawati, E. Y. S. , dkk. (2018). Efektivitas Instrumen Asesmen Model Creative Problem Solving pada Pembelajaran Fisika Terhadap Kemampuan Berpikir Kritis Siswa. Jurnal Pendidikan Fisika, 6 (2), 128-143.

Asniarny. (2019). Pelaksanaan Supervisi Akademik Pengawas Sekolah dalam Meningkatkan Kinerja Guru Sekolah Dasar di Kota Dumai. Jurnal PAJAR (Pendidikan dan Pengajaran), 3 (4), 764-772.

Asnidawati. (2019). Kompetensi Guru dalam Menyusun Rencana Pelaksanaan Pembelajaran (RPP) Melalui Supervisi Akademik di SD Negeri 004 Sungai Manau. Jurnal PAJAR (Pendidikan dan Pengajaran), 3 (5), 1120-1128.

Baharuddin. (2019). Meningkatkan Kompetensi Guru dalam Memilih Model Pembelajaran melalui Kegiatan Suvervisi Akademik di SD Negeri 004 Dusun Tua Kecamatan Kelayang Kabupaten Indragiri Hulu. Jurnal PAJAR (Pendidikan dan Pengajaran), 3 (1), 53-60.

Basri, M. (2019). Meningkatkan Profesionalisme Guru Membuat Rencana Pelaksanaan Pembelajaran (RPP) Melalui Supervisi Bimbingan Pribadi di SDN 91/IX Rengas Bandung. Jurnal PAJAR (Pendidikan dan Pengajaran), 3 (5), 1003-1014. mengalami peningkatan dari $68 \%$ pada siklus I meningkat menjadi $82 \%$ pada siklus II.

Mengacu pada hasil dan pembahasan yang telah dikemukakan maka rekomendasi untuk penelitian selanjutnya adalah bahwa untuk membuat tes diperlukan pemahaman materi, kesiapan bahan, serta bimbingan yang berkesinambungan agar instrumen tes yang disusun dapat mengukur kemampuan siswa sesuai dengan tujuan pembelajaran dan kompetensi dasar yang ditetapkan dalam kurikulum.

Gusmarni. (2019). Meningkatkan Kompetensi Guru dalam Menyusun Butir Soal melalui Kegiatan Workshop di Sekolah Dasar. Jurnal PAJAR (Pendidikan dan Pengajaran), 3 (5), 1129-1136.

Kadarwati, A. (2017). Peningkatan Kompetensi Calon Pendidik SD Dalam Pengembangan Tes Hasil Belajar. Premiere Educandum, 7 (1) $76-86$.

Kasiono, D. (2019). Peningkatan Kemampuan Menyusun Soal dengan Metode Pendampingan Berpola SP3R pada Guru SDN Sepanyul Kecamatan Gudo Kabupaten Jombang Tahun 2018. Jurnal Dinamika Manajemen Pendidikan, 4 (1) 33-41

Kartimi \& Liliasari. (2012). Pengembangan Alat Ukur Berpikir Kritis Pada Konsep Termokimia Untuk Siswa SMA Peringkat Atas Dan Menengah. Jurnal Pendidikan IPA Indonesia, 1 (1), 21-26.

Marimin. (2017). Upaya Meningkatkan Kemampuan Guru dalam Menyusun Tes Hasil Belajar Akhir Semester I melalui Supervisi Akademik Pada Kelas V Dabin II Pattimura Kecamatan Jatiyoso Tahun Pelajaran 2016/2017. Jurnal Ilmiah Mitra Swara Ganesha, 4 (1), 37-57.

Rambe, M. (2019). Pelaksanaan Supervisi Akademik Sebagai Upaya untuk Meningkatkan Kompetensi Guru dalam Menyusun Rencana Pelaksanaan 
Jurnal PAJAR (Pendidikan dan Pengajaran)

Volume 3 Nomor 6 November 2019 |ISSN Cetak : 2580 - 8435 |ISSN Online : 2614 - 1337

DOI : http://dx.doi.org/10.33578/pjir.v3i6.7896

Pembelajaran. Jurnal PAJAR (Pendidikan dan Pengajaran), 3 (4), 782-790.

Sudijono, A. (2011). Pengantar Evaluasi Pendidikan. Jakarta: PT RajaGrafindo Persada. 